\title{
I.UMIBUNG
}

\section{ISOLASI DAN IDENTIFIKASI BAKTERI PELARUT FOSFAT DARI TANAH RHIZSOSFER KELAPA SAWIT (Eleis guineensis)}

\author{
Asrul $^{1}$ dan I Nyoman Pugeg Aryantha ${ }^{2}$ \\ ${ }^{1)}$ Staff Pengajar Politeknik Pertanian Negeri Kupang \\ ${ }^{2)}$ Staff Pengajar Institut Teknologi Bandung \\ Korespondensi: asrulindonesia@yahoo.co.id
}

$\begin{array}{ll}\text { Diterima } & : \text { 29 Januari } 2020 \\ \text { Disetujui } & : \text { 25 Februari } 2020 \\ \text { Diterbitkan } & : \text { 29 Februari } 2020\end{array}$

\begin{abstract}
ABSTRAK
Bakteri sebagai salah satu agent penyubur tanah, masih sangat minim diketahui petani. Kenyataannya bakteri mampu menyediakan unsur hara makro yang dibutuhkan oleh tanaman, contohnya fosfat. Fosfat di tanah umumnya dalam bentuk terikat, baik yang berbentuk anorganik (Ca-P, Fe-P dan Al-P) maupun organik (asam nukleat dan fosfolipida). Mengeksresikan asam organik, merupakan cara umum bakteri untuk melarutkan fosfat terikat khususnya yang anorganik. Isolasi bakteri pelarut fosfat dilakukan di tanah rhizosper Kelapa Sawit (Eleis guineensis) PT Astra Agro Lestari dengan menggunakan media pikovskaya yang di dalamnya terdapat kalsium fosfat (Ca-P). Hasilnya ada 6 bakteri yaitu A2, B5, C7, F1, F2, dan $\mathrm{K} 1$ yang mampu melarutkan kalsium fosfat (Ca-P). Uji kuantitatif dengan menggunakan spektrofotometer $410 \mathrm{~nm}$, pada supernatant pikovskaya cair menunjukkan bakteri A2 mampu melarutkan fosfat 20,40 ppm paling baik jika dibandingkan dengan bakteri, $\mathrm{C} 7=7,69 \mathrm{ppm}$, $\mathrm{F} 1=5,77 \mathrm{ppm}, \mathrm{F} 2=5,53 \mathrm{ppm}, \mathrm{B} 5=1.19 \mathrm{ppm}$ dan $\mathrm{K} 1=0,46 \mathrm{ppm}$. Identifikasi partial sequences 16s rRNA menunjukkan bakteri A2 putative Amycolatopsis albidoflavus.
\end{abstract}

Keywords: amycolatopsis albidoflavus bakteri, fosfat, kelapa sawit, rhizosper

\begin{abstract}
Bacteria as one of the soil fertility agents, are still very little known to farmers. In fact, bacteria are able to provide macro nutrients needed by plants, for example phosphate. Phosphate in the soil is generally in the form of bound, both inorganic form (Ca-P, Fe-P and Al-P) and organic (nucleic acids and phospholipids). Excreting organic acids, is a common way for bacteria to dissolve bound phosphates, especially inorganic ones. Isolation of phosphate solubilizing bacteria was carried out in the palm oil rhizosper (Eleis guineensis) PT Astra Agro Lestari by using pikovskaya media which contained calcium phosphate (Ca$P$ ). The result is that there are 6 bacteria namely A2, B5, C7, F1, F2, and K1 which are able to dissolve calcium phosphate $(\mathrm{Ca}-\mathrm{P})$. A quantitative test using a $410 \mathrm{~nm}$ spectrophotometer, the liquid supernatant pikovskaya showed that A2 bacteria was able to dissolve phosphate 20.40 ppm best when compared with bacteria, $C 7=7.69 \mathrm{ppm}, F 1=5.77 \mathrm{ppm}, F 2=5.53$ ppm, B5 = $1.19 \mathrm{ppm}$ and $K 1=0.46 \mathrm{ppm}$. Identification of partial sequences of $16 \mathrm{~s} r R N A$ showed putative A2 bacteria Amycolatopsis albidoflavus.
\end{abstract}

Keywords: amycolatopsis albidoflavus bacteria, palm oil, phophate, rhisopere 


\section{I.UMIBUNG}

\section{PENDAHULUAN}

Fosfat termasuk unsur hara makro yang dibutuhkan tanaman untuk proses tumbuh kembangnya. Proses pembelahan sel, fotosinstesis, pertumbuhan, pembentukan tepung dan terbentuknya formasi nukleus merupakan peran fosfat di tanaman (McKenzie \& Middleton, 2013). Fosfat di tanah dibagi atas dua bagian yaitu fosfat organik yang berasal dari mineralisasi bahan organik di tanah dan fosfat anorganik, baik yang terikat dengan besi, kalsium, dan aluminium, ataupun dalam bentuk mineral apatite (Munawar, 2011).

Fosfat meskipun termasuk unsur hara makro dan terdapat dalam berbagai macam bentuk di tanah, namun keberadaanya dalam bentuk dapat diserap oleh tanaman sangat terbatas. Tanaman hanya mampu menyerap fosfat dalam bentuk ion ortofosfat yaitu $\mathrm{HPO}_{4}{ }^{2-}$ dan $\mathrm{H}_{2} \mathrm{PO}_{4}$ (Syers dkk., 2008). Umumnya fosfat dalam bentuk anorganik, Ca-P, Al-P dan Fe$\mathrm{P}$ yang melimpah di tanah tidak bisa diserap oleh tanaman, terlebih lagi jika masih dalam bentuk fosfat organic yaitu inositol fosfat, asam nukleat dan fosfolipida (Munawar, 2011).

Mengubah fosfat terikat menjadi terlarut dapat dilakukan dengan bantuan bakteri pelarut fosfat. Bacillus, Agrobacterium, Pseudomonas, Erwinia, Azotobacter dan Streptomyces merupakan contoh bakteri yang mempunyai kemampuan melarutkan fosfat (Zhu dkk., 2011). Memproduksi asam organik atau anorganik, H2S, siderophore, serta menurunkan derajat keasaman tanah dengan mengeksresikan $\mathrm{H}^{+}$merupakan jalan bagi bakteri untuk melarutkan fosfat anorganik, sedangkan untuk memineralisasi fosfat organik dengan memproduksi enzim phosphatase, pytase dan C-P lyasase (Sharma dkk., 2013).

Perkebunan kelapa sawit salah satu sektor pertanian yang kebutuhan akan pupuk fosfatnya sangat tinggi. Menurut Allorerung dkk., (2010) umur tanaman, jenis tanah dan kondisi penutup tanah sangat mempengaruhi dosis pemberian pupuk pada tanaman sawit khususnya fosfat. Rock fosfat merupakan pupuk anorganik yang umumnya diberikan pada tanaman sawit (Allorerung dkk., 2010).

Menurut Tirado dan Allsopp (2012), pupuk fosfat (anorganik) yang umumnya digunakan petani, mengandung logam berat kadmium yang sangat berbahaya bagi kesehatan manusia jika terkonsumsi melalui olahan makanan dari tanaman yang terkontaminasi. Ditambah pupuk anorganik sebagai penopang kebutuhan akan fosfat, mempunyai turunan berbahaya bagi kesehatan selain kadmium. Oleh karena itu perlu ada upaya untuk memanfaatkan jasa bakteri untuk memenuhi kebutuhan akan tersedianya fosfat terserap di tanah. 


\section{I.UMIBUNG}

\section{METODE PENELITIAN}

Sampling tanah rhizosper kelapa sawit dilakukan di area perkebunan PT Astra Agro Lestari, Pangkalan Bun dan dianalisis lebih lanjut di Lab GBB PAU lantai 6 ITB. Penelitian ini dilaksanakan Agustus-Desember 2015. Tanah sampling seberat $1 \mathrm{~g}$ dimasukkan ke dalam $9 \mathrm{ml} \mathrm{NaCl}$ fisiologis steril lalu dihomogenkan dengan vortex. Hasilnya $1 \mathrm{ml}$ suspensi yang sudah homogen diencerkan di $9 \mathrm{ml} \mathrm{NaCl}$ fisiologis steril sampai pada tingkat pengenceran $10^{-5}$

Hasil pengenceran $10^{-4}$ dan $10^{-5}$ diambil $1 \mathrm{ml}$ dan diteteskan di media NA (natrium agar), kemudian disebar dengan batang L steril. Kurang lebih 24 jam, koloni bakteri yang sudah tumbuh di media NA, diamati morfologinya. Mulai dari bentuk, warna, tepian dan elavasi dari koloni bakteri.

Uji kualitatif bakteri pelarut fosfat dilakukan dengan cara isolat bakteri ditumbuhkan pada media pikovskaya padat. Komposisi pikovskaya mengacu pada protokol pabrikan Himedia (2011) yang terdiri dari yeast ekstrak 0.5 (g/L), dekstrosa 10 (g/L), fosfat kalsium 5 $(\mathrm{g} / \mathrm{L})$, ammonium sulfat $0.5(\mathrm{~g} / \mathrm{L})$, potassium klorida $0.2(\mathrm{~g} / \mathrm{L})$, magnesium sulfat $0.1(\mathrm{~g} / \mathrm{L})$, mangan sulfat $0.0001(\mathrm{~g} / \mathrm{L})$, besi sulfat $0.0001(\mathrm{~g} / \mathrm{L}), \mathrm{pH} 7,2 \pm 0,2$, dan ditambahkan agar 20 $\%(\mathrm{~g} / \mathrm{L})$ jika pikovskaya padat.

Uji kuantitatif bakteri pelarut fosfat dilakukan dengan cara menumbuhkan isolat bakteri terpilih di media pikovskaya cair dengan ditambahkan dengan 3-kalsium fosfat dan diinkubasi selama 5 hari dengan cara di shaker $150 \mathrm{rpm}$. Pikovskaya cair plus bakteri kemudian disentrifugasi selama 30 menit dengan kecepatan $10.000 \mathrm{rpm}$ dan supernatannya dianalisis dengan spektrofotometer pada panjang gelombang $410 \mathrm{~nm}$ (Karpagam \& Nagalakshmi, 2014). Nilai absorbansi supernatant yang didapatkan kemudian dikonversi menjadi ppm dengan rumus (absorbansi supernatant $=0.0083 * \mathrm{ppm} \mathrm{KH}_{2} \mathrm{PO}_{4}+0.0211$ ) dengan rujukan kurva standar $\mathrm{KH}_{2} \mathrm{PO}_{4}$

Identifikasi bakteri pelarut fosfat dilakukan dengan dua metode yaitu dengan pewarnaan sel bakteri dan amplifikasi nukleotida penyusun 16s rRNA. Pewarnaan sel bakteri dilakukan pada semua bakteri yang mampu melarutkan fosfat, namun amplifikasi nukleotida 16s rRNA hanya dilakukan pada bakteri yang mempunyai kemampuan terbaik melarutkan fosfat secara kuantitatif.

Pewarnaan sel bakteri dimulai dengan pembuatan apusan kering, pewarnaan dengan reagen metilen biru, karbol fuchsin, safranin, dan kristal violet. Hasil pewarnaan kemudian 


\section{I.UMIBUNG}

diamati di bawah mikroskop. Warna biru / ungu menandakan bakteri gram positif sedangkan warna merah menandakan bakteri gram negatif. Amplifikasi nukleotida 16s rRNA menggunakan primer forward 785F (GGATTAGATACCCTGGTA) dan primer reverse 907R (CCGTCAATT CMTTTRAGTTT), dilakukan di Macrogen. Hasilnya kemudian diolah dengan bioedit dan di Blast di NCBI untuk menentukan strain bakterinya.

\section{HASIL DAN PEMBAHASAN}

Total tanah rhizosper yang disampling dari perkebunan PT Agro Lestari ada 20 kantong dengan jumlah bakteri yang berhasil diisolasi yaitu 103. Keberadaan bakteri di rhizosper dipengaruhi oleh adanya eksudat yang dikeluarkan oleh tanaman (Widyati, 2013). Jumlah 103 isolat bakteri didapatkan dari proses seleksi morfologi bakteri mulai dari bentuk koloni, elavasi, tepian, warna dan diameter koloni.

Morfologi bakteri yang sama di satu kode tanah sampel yang sama tidak dihitung lagi, namun jika berbeda sampel tanah tetap dihitung. Hal ini dilakukan untuk meminimalisir terbuangnya strain atau genus bakteri yang berbeda meskipun bentuk morfologi sama. Hasil penelitian Marista dkk., (2013) memperlihatkan bakteri BPFAL 5 dari tanah alluvial dan BPFGM 5 dari tanah gambut meskipun secara bentuk morfologi sama namun BPFAL 5 termasuk genus Flavabaterium dan BPFGM 5 genus Azetobacter.

Hasil Uji kualitatif ditemukan 6 bakteri yang mampu melarutkan fosfat yaitu B5, C7, F1, F2, A2, dan K1. Bakteri yang positif melarutkan fosfat ditandai dengan adanya zona bening di media pikovskaya (gambar 1). Fosfat yang terikat yang berhasil dilarutkan dari bakteri tersebut adalah kalsium-fosfat (Ca-P) yang terdapat di media pikovskaya. Asam sitrat, asam tartart, dan asam malat merupakan asam organik yang umumnya dihasilkan oleh bakteri untuk melarutkan kalsium-fosfat yang terdapat di media pikovskaya (Prijambada dkk., 2009).

Tabel 1. Bentuk dan hasil pewarnaan gram bakteri yang teridentifikasi mampu melarutkan fosfat.

\begin{tabular}{cccccccc}
\hline No & Kode Bakteri & A2 & B5 & C7 & F1 & F2 & K1 \\
\hline $\mathbf{1}$ & Bentuk & Basil & Basil & Cocus & Basil & Basil & Basil \\
& & panjang & Pendek & & & & \\
\multirow{2}{*}{2} & Pewarnaan / Gram & Ungu / & Merah & Ungu & Ungu & Merah / & Merah / \\
& & Positif & Negatif & Positif & Positif & Negatif & Negatif \\
\hline
\end{tabular}




\section{I.UMIBUNG}

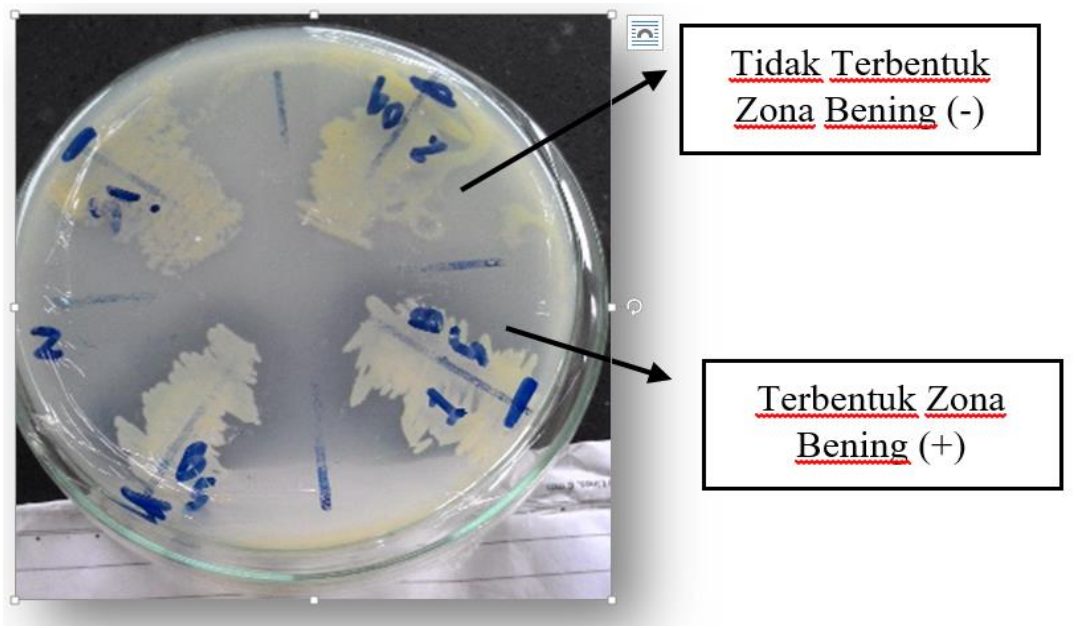

Gambar 1. Hasil uji kualitatif isolat bakteri pelarut fosfat ditandai dengan terbentuknya zona bening disekitar koloni

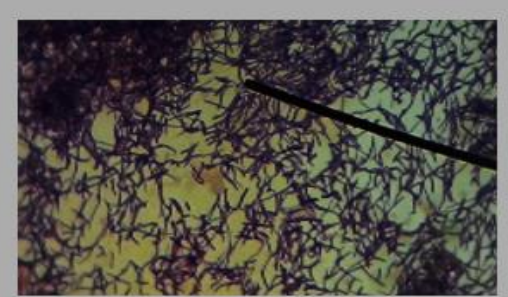

A2,

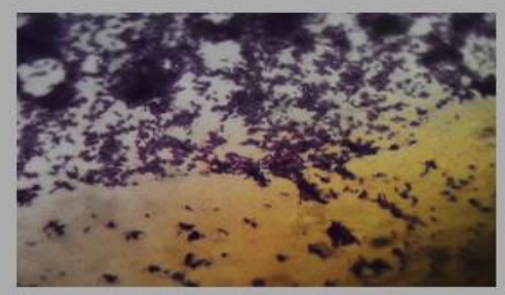

F1

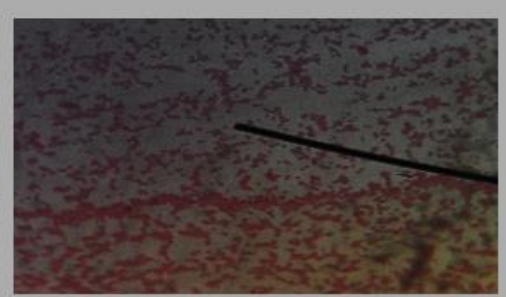

B5,

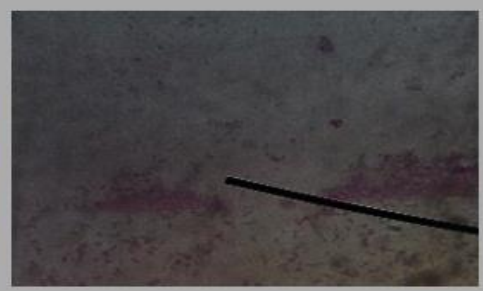

F2

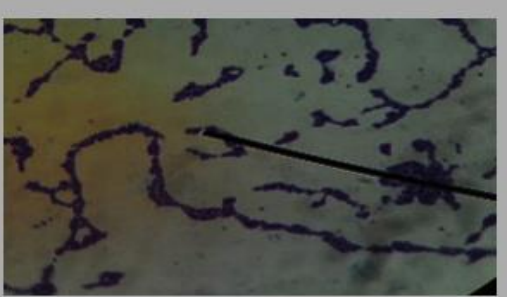

C7

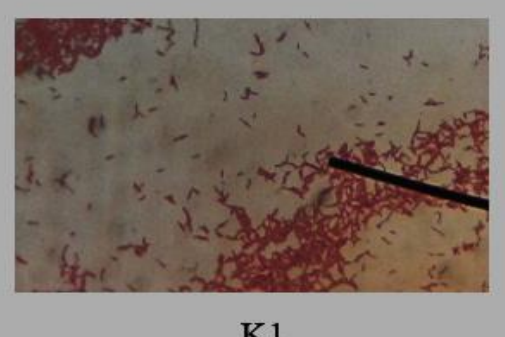

K1

Gambar 2. Hasil pewarnaan gram pada bakteri yang teridentifikasi mampu melarutkan fosfat.

Hasil pewarnaan gram pada bakteri pelarut fosfat memperlihatkan 3 bakteri termasuk gram positif yaitu A2, C7 dan F1. Adapun tiga sisanya B5, F2 dan K1 termasuk gram negatif (gambar 2 dan tabel 1). Menurut Krishnaraj dan Dahale (2014), fosfat yang terikat dapat dilarutkan baik dari bakteri gram positif maupun gram negatif. Sebaran bentuk bakteri pelarut fosfat umumnya didominasi basil yaitu A2, B5, F1, F2, dan K1, sedangkan sisanya C7 bentuknya cocus.

Hasil isolasi bakteri pelarut fosfat dari tanah rhizosfer Umbi Cilembu (Ipomoea batatas L var. Rancing), dua kelompok bakteri Fimicutes dan Proteobacteria merupakan bakteri gram negatif dan sisanya yaitu Actinomycetes termasuk gram positif (Amelia \& 


\section{I.UMIBUNG}

Aditiawati, 2016). Azotobacter, Acetobacter, Escherichia, Flavobacterium, merupakan genus bakteri gram negatif yang mampu melarutkan fosfat, sedangkan dari golongan gram positif terdapat Staphylococcus (Marista dkk., 2013).

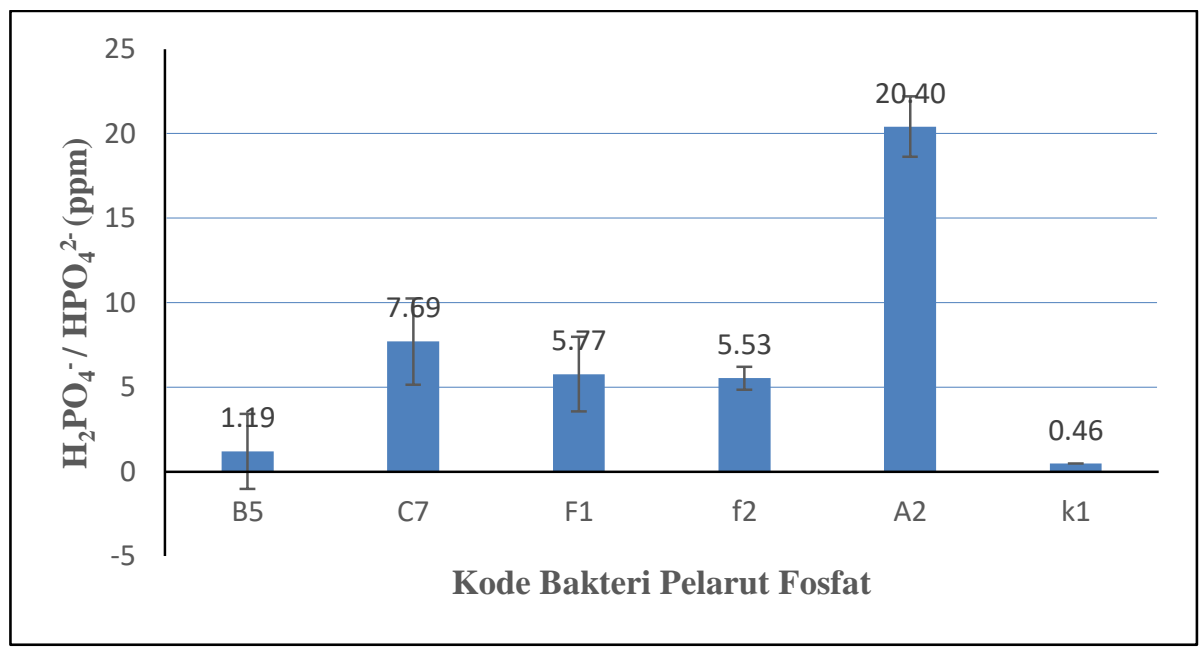

Tabel 2. Hasil uji kuantitatif isolat bakteri pelarut fosfat dengan spektrofotometer pada panjang gelombang $410 \mathrm{~nm}$

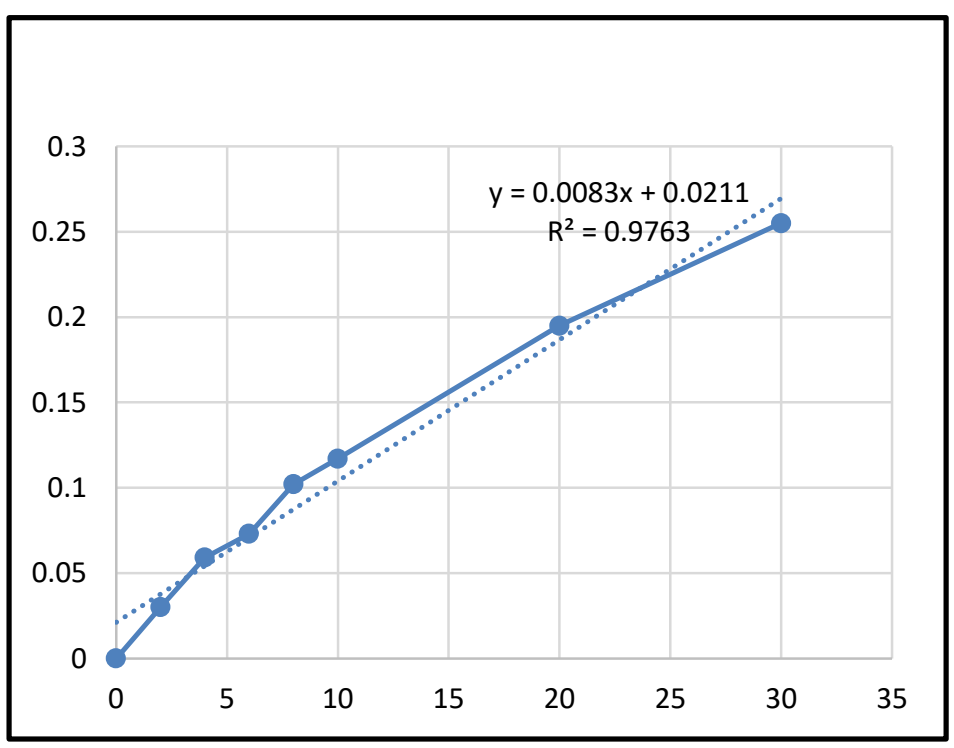

\begin{tabular}{|c|c|}
\hline \multicolumn{2}{|c|}{$\mathrm{KH}_{2} \mathrm{PO}_{4}$} \\
\hline Ppm & Abs \\
\hline 0 & 0 \\
\hline 2 & 0.03 \\
\hline 4 & 0.059 \\
\hline 6 & 0.073 \\
\hline 8 & 0.102 \\
\hline 10 & 0.117 \\
\hline 20 & 0.195 \\
\hline 30 & 0.255 \\
\hline
\end{tabular}

Tabel 3. Kurva standar Fosfat $\left(\mathrm{KH}_{2} \mathrm{PO}_{4}\right.$, abs 410$)$ 


\section{I.UMIRUNC}

Hasil uji kuantitatif dari 6 bakteri pelarut fosfat (tabel 2) memperlihatkan bahwa bakteri kode A2 memiliki kemampuan tinggi melarutkan fosfat dengan jumlah fosfat tersedia $\left(\mathrm{H}_{2} \mathrm{PO}_{4}{ }^{-} / \mathrm{H}_{2} \mathrm{PO}_{4}{ }^{2-}\right)$ yaitu $20.40 \mathrm{ppm}$, disusul kemudian $\mathrm{C} 7=7.69 \mathrm{ppm}, \mathrm{F} 1=5.77$ ppm, $\mathrm{F} 2=5.53 \mathrm{ppm}, \mathrm{B} 5=1.19$, dan $\mathrm{K} 1=0.46 \mathrm{ppm}$. Hasil data ppm diperoleh dari konversi absrobansi masing-masing bakteri ke kurva standar $\mathrm{KH}_{2} \mathrm{PO}_{4}$ (tabel 3)

Asam laktat, asam sitrat, asam fumirat, asam aspartat, asam glukonat, asam oksalat, asam 2-glukonat dan asam suksinat merupakan asam organik yang umumnya diproduksi oleh bakteri untuk melarutkan fosfat (Alori dkk., 2017). Namun demikian asam glukonat yang sering terdeteksi pada proses pelarutan fosfat anorganik oleh bakteri pelarut fosfat (Rogríguez \& Fraga, 1999). Asam glukonat diperoleh dari aktivitas D-glukosa dehidroginase dalam mengoksidasi glukosa (Sharma dkk., 2005).

Kemampuan bakteri A2 paling baik untuk melarutkan fosfat dibandingkan dengan B5, C7, F1, F2 dan K1, bisa saja berubah jika fosfat terikat di media pikovskaya diganti dengan aluminium-fosfat atau besi-fosfat bukan lagi kalsium-fosfat. Hasil penelitian Prijambada dkk., (2009) memperlihatkan isolat bakteri G2, T1 dan U1 mempunyai kemampuan sama dalam melarutkan tiga kalsium fosfat, namun saat diganti dengan besi-sulfat, maka isolat bakteri T1 paling baik diantara G2 dan U1.

Partial sequence $16 \mathrm{~S}$ rRNA bakteri A2 yang di Blast di NCBI kemudian ditentukan kekerabatannya dengan bakteri lainnya dengan menggunakan program Mega 7 (gambar 3). Hasilnya memperlihatkan bahwa bakteri A2 termasuk golongan bakteri Amycolatopsis albidoflavus dengan nilai query cover dan keidentikannya mencapai 100 $\%$. Jadi dapat disimpulkan bahwa bakteri A2 adalah putative Amycolatopsis albidoflavus.

Penelitian tentang bakteri Amycolatopsis albidoflavus yang berhubungan dengan proses pelarutan fosfat, sejauh ini belum ditemukan jurnal yang membahasnya, namun demikian Tchakounté., dkk (2018) berhasil mengisolasi 2 bakteri yang bergenus Amycolatopsis yang mampu melarutkan fosfat. Amycolatopsis albidoflavus merupakan bakteri gram positif (Lee \& Hah, 2001). Hal ini sejalan data pengamatan yang ditampilkan pada tabel 1. Amycolatopsis albidoflavus mampu menghasilkan $\mathrm{H}_{2} \mathrm{~S}$ (Lee \& Hah, 2001). Salah satu mekanisme pelarutan fosfat anorganik oleh bakteri yaitu dengan memproduksi $\mathrm{H}_{2} \mathrm{~S}$ (Sharma dkk., 2013). 


\section{I.UMIBUNG}

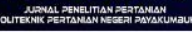

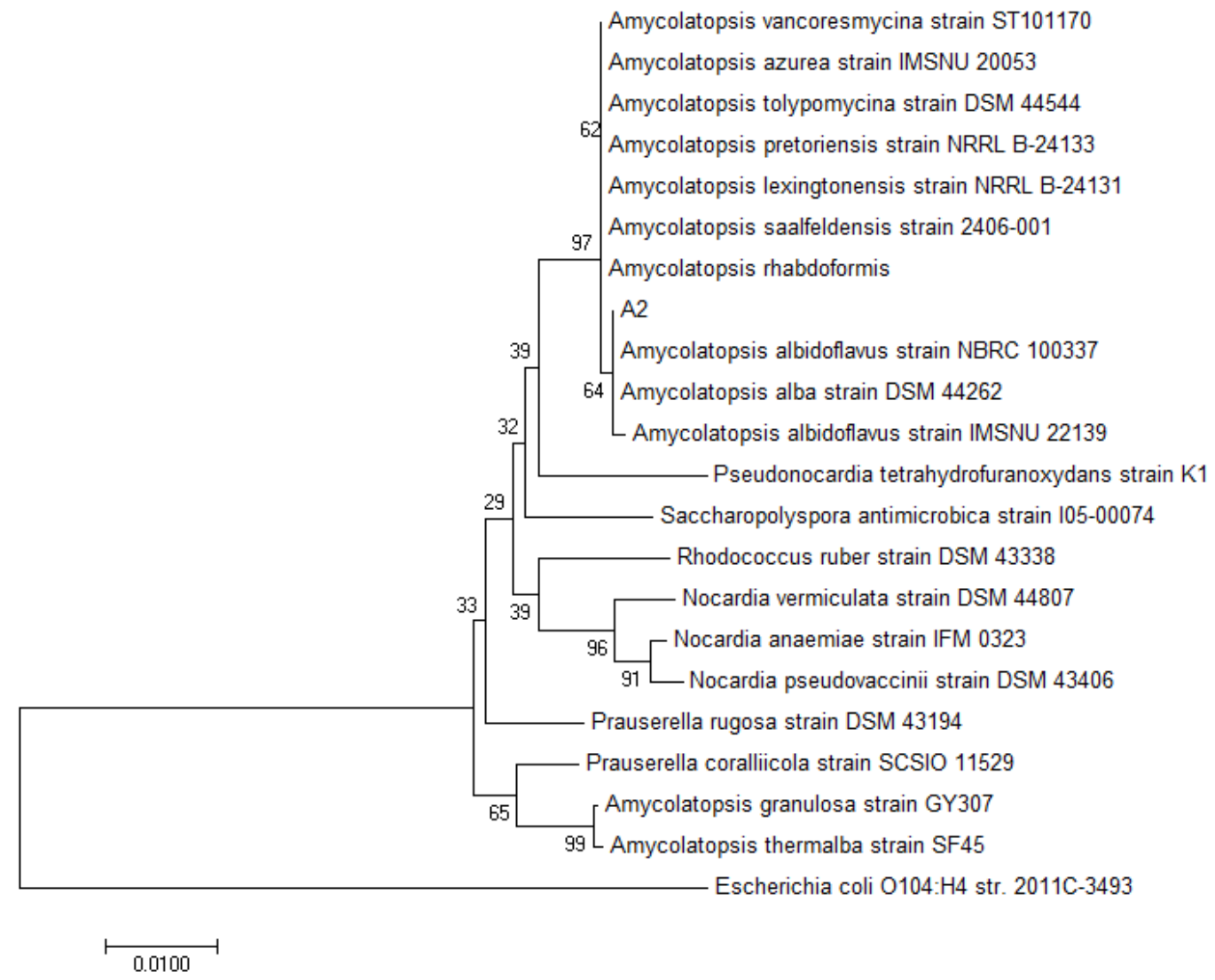

Gambar 3. Pohon filogenetik isolat bakteri A2

\section{KESIMPULAN DAN SARAN}

\section{Kesimpulan}

1. Bakteri mampu menjadi agen penyedia unsur hara fosfat terserap bagi tanaman khususnya kelapa sawit (Eleis guineensis).

2. Ada sekitar 6 bakteri yang mampu melarutkan fosfat di tanah rhizosper kelapa sawit (Eleis guineensis)

3. Bakteri Amycolatopsis albidoflavus mampu melarutkan fosfat khususnya yang terikat pada kalsium.

\section{Saran}

1. Perlu dilakukan penelitian lebih lanjut akan uji kuantitatif bakteri pelarut fosfat A2, C7, F1, F2, B5 dan K1 terhadap fosfat yang terikat pada aluminium dan besi 


\section{I.UMIRUNC}

\section{REFERENSI}

Allorerung, D., Syakir, M., Poeloengan, Z., Syafaruddin, \& Rumini, W. 2010. Budidaya Kelapa Sawit. Aska Media , Bogor.

Alori, E. T., Glick, B. R., \& Babalola, O. O. 2017. Microbial Phosphorus Solubilization and Its Potential for Use in Sustainable Agriculture. Frontiers in Microbiology, 8 : 971.

Amelia, R., \& Aditiawati, P. 2016. Keanekaragaman Bakteri Rizosfer Pemacu Pertumbuhan Tanaman (Plant Growth Promoting Rhizobacteria / PGPR ) selama Pertumbuhan Ubi Jalar Cilembu (Ipomoea batatas L var . Rancing ) Prosiding SNIPS, 899-906.

Himedia. (2011). Pikovskaya 's Broth (Medium). Diakses dari http://himedialabs.com/ TD/M1719.pdf

Karpagam, T., \& Nagalakshmi, P. 2014. Isolation and Characterization of Phosphate Solubilizing Microbes from Agricultural Soil. International Journal of Current Microbiology and Applied Sciences, 3(5), 601-614.

Krishnaraj, P. U., \& Dahale, S. 2014. Mineral Phosphate Solubilization: Concepts and Prospects in Sustainable Agriculture. Proceedings of the Indian National Science Academy, 80(2), 389-405.

Lee, S. D., \& Hah, Y. C. (2001). Amycolatopsis albidoflavus sp. nov. International Journal of Systematic and Evolutionary Microbiology, 51(2), 645-650.

Marista, E., Khotimah, S., D., \& Linda, R. 2013. Bakteri Pelarut Fosfat Hasil Isolasi dari Tiga Jenis Tanah Rizosfer Tanaman Pisang Nipah (Musa paradisiaca var. nipah) di Kota Singkawang. 2(2), 93-101.

McKenzie, R. H., \& Middleton, A. 2013. Phosphorus Fertilizer Application in Crop Production. Agdex, 542(3).

Munawar A. 2011. Kesuburan Tanah dan Nutrisi Tanaman. Bogor: IPB Press.

Prijambada, I. D., Widada, J., Kabirun, S., \& Widianto, D. (2009). Secretion of Organic Acids by Phosphate Solubilizing Bacteria Isolated from Oxisols. Jurnal Tanah Tropika (Journal of Tropical Soils), 14(3), 245-251.

Rogríguez, H \& Fraga, R. 1999. Phosphate Solubilizing Bacteria and Their Role in Plant Growth Promotion. Biotechnology Advances, 17, 319-339.

Sharma, S. B., Sayyed, R. Z., Trivedi, M. H., \& Gobi, T. A. 2013. Phosphate Solubilizing Microbes: Sustainable Approach for Managing Phosphorus Deficiency in Agricultural Soils. SpringerPlus, 2:587.

Sharma, V., Kumar, V., Archana, G., \& Kumar, G. N. 2005. Substrate Specificity of Glucose Dehydrogenase (GDH) of Enterobacter asburiae PSI3 and Rock 


\section{I.UMIBUNG}

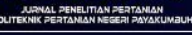

Phosphate Solubilization with GDH Substrates as C Sources . Canadian Journal of Microbiology, 51, 477-482.

Syers, J., Johnston, A., \& Curtin, D. 2008. Efficiency of Soil and Fertilizer Phosphorus Use: Reconciling Changing Concepts of Soil Phosphorus Behaviour with Agronomic Information. FAO Fertilizer and Nutrition Bulletin, 18.

Tchakounté, G. V. T, Berger, B., Patz, S., Fankem, H., \& Ruppel, S. 2018. Community Structure and Plant Growth-Promoting Potential of Cultivable Bacteria Isolated from Cameroon Soil. Microbiological Research, 214, 47-59.

Tirado, R., \& Allsopp, M. 2012. Phosphorus in Agriculture Problems and Solutions. Greenpeace Research Laboratories Technical Report, Amsterdam.

Widyati, E. 2013. Memahami Interaksi Tanaman - Mikroba.Tekno Hutan Tanaman, 6(1), 13-20.

Zhu, F., Qu, L., Hong, X., \& Sun, X. 2011. Isolation and Characterization of a Phosphate-Solubilizing Halophilic Bacterium Kushneria sp. YCWA18 from Daqiao Saltern on the Coast of Yellow Sea of China . Evidence-Based Complementary and Alternative Medicine, 2011, 1-6. 